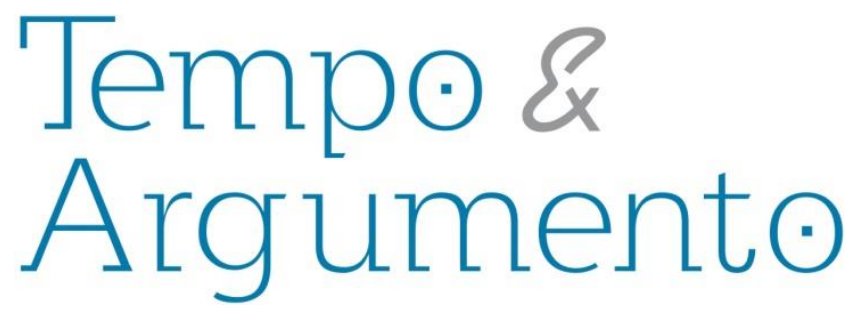

\title{
Estado e movimentos sociais negros (1980-2010)
}

\section{Resumo}

Este artigo visa comparar a relação entre Estado e movimentos sociais negros (1980-2010). Nesse sentido, objetiva analisar os discursos presidenciais em relação às demandas sociais dos movimentos negros nos governos de José Sarney (1985-1990), Fernando Henrique Cardoso (1995-2003) e Luís Inácio Lula da Silva (2003-2010). Paralelamente, almeja analisar a gênese e objetivos das instituições de recorte racial encabeçadas pelo Poder Executivo, quais sejam, a Fundação Cultural Palmares (1988) e a Secretaria Especial de Promoção da Igualdade Racial (Seppir) (2010). Para metodologia, adota a revisão de literatura quanto ao tema em tela, bem como propõe a análise discursiva amparada em " $\mathrm{A}$ Arqueologia do Saber" (2007) de Michel Foulcault (1926-1984).

Palavras-chave: Discursos Presidenciais. Preto. Raça.

\section{Fernanda Barros dos Santos}

Doutora em Ciência Política pela Universidade Federal Fluminense (UFF). Professora na Universidade Federal do Rio de Janeiro.

$$
\text { (UFRJ). }
$$

Rio de Janeiro - RJ - Brasil fernandabs21@yahoo.com.br

\section{Para citar este artigo:}

SANTOS, Fernanda Barros dos. Estado e movimentos sociais negros (1980-2010). Tempo e Argumento, Florianópolis, v. 10, n. 25, p. 144 -182, jul./set. 2018.

\section{DOI: $10.5965 / 2175180310252018144$}

http://dx.doi.org/10.5965/2175180310252018144 


\title{
State and Black Social Movements
}

\section{(1980-2010)}

\begin{abstract}
This article aims to compare the relation between State and black social movemments. In this purpose, analyzes the responses of the presidential speeches regarding the social demands of the Black Movement This article aims at a relationship between State and social management (1980-2010). In this sense, the objective was to disseminate presidential speeches at social levels of black managers in the governments of José Sarney (1985-1990), Fernando Henrique Cardoso (1995-2003) and Luís Inácio Lula da Silva (2003-2010). In parallel, they have been the genesis and objectives of organizations in the development of the Races of Equivalence for the Performing Facility (1988) and the Special Secretariat for the Promotion of Racial Equality (2010). Methodologically, the journal of analysis of the subject to the subject, as well as a discursive analysis in "The Archeology of the Saber" (2007) of Michel Foulcault (1926-1984).
\end{abstract}

Keywords: Presidential Speeches. Black. Breed.

\section{A Conferência de Durban (2001) e seus desdobramentos no cenário brasileiro}

Em agosto de 2001, a Conferência de Durban, ocorrida na África do Sul e organizada pelas Nações Unidas, reuniu diversos movimentos sociais, inclusive a militância negra brasileira. De acordo com Sueli Carneiro, a Conferência Mundial contra o Racismo reuniu uma equipe brasileira composta de lideranças, organizações negras, organizações sindicais que assumiram diversas tarefas organizativas (CARNEIRO, 2002).

Nesse sentido, o Comitê brasileiro foi responsável pelo Fórum Nacional de Entidades Negras para a III Conferência contra o Racismo na África do Sul. Em consonância, a delegação trouxe para o debate internacional as peculiaridades do racismo no Brasil e a urgência de medidas que estimulassem a simetria entre negros e brancos nos principais canais de acesso a bens e poder (educação, mercado de trabalho e outros). Diante deste cenário, se concebeu parte da agenda dos militantes negros em Durban, qual seja, a adoção das ações afirmativas na educação superior ( CARNEIRO, 2002, p. 210). 
Em 2003, sob acalorado debate na Assembleia Legislativa do Estado do Rio de Janeiro (ALERJ), a Universidade Estadual do Rio de Janeiro (UERJ) implementou as cotas sociais e raciais sob iniciativa do Governador Anthony Garotinho. Posteriormente, em 2012, foram ratificadas pelo Supremo Tribunal de Justiça (STJ) sob a forma da Lei $\left(n^{\circ}\right.$ 12.711). Apesar das vozes dissonantes, as mesmas foram inseridas nas universidades públicas de todo país (GUARNIEIRI; SILVA, 2017, p. 184).

Portanto, a pertinência deste estudo reside na análise da interação entre atores sociais díspares, quais sejam, Estado e movimentos sociais negros ${ }^{1}$. Assim como, percorre os primeiros discursos estatais relacionados com a demanda racial, a exemplo da Presidência de José Sarney.

\section{José Sarney (1985-1990) e a criação da Fundação Cultural Palmares (1988)}

Anterior à Conferência de Durban em 2001, cabe retomar a década de 1990 e apreciar o discurso de criação da Fundação Cultural Palmares ${ }^{2}$ na Presidência de José Sarney (1985-1990).

Fato era que o discurso se reportava à Marcha contrária à Comemoração do Centenário da Abolição (1988) idealizada à época pela Presidência da República. Em 11 de maio de 1988, no Rio de Janeiro, de acordo com Abreu (2014), ocorreu a Marcha contra a Farsa da Abolição, um protesto que reuniu mais de 5 mil pessoas no centro da cidade,

\footnotetext{
${ }^{1}$ Esta pesquisa assume a perspectiva de Joel Rufino acerca da conceituação dos movimentos negros, qual seja, "todas as entidades, de qualquer natureza, e todas as ações, de qualquer tempo [aí compreendidas mesmo aquelas que visavam à autodefesa física e cultural do negro], fundadas e promovidas por pretos e negros (...). Entidades religiosas [como terreiros de candomblé, por exemplo], assistenciais [como as confrarias coloniais], recreativas [como "clubes de negros"], artísticas [como os inúmeros grupos de dança, capoeira, teatro, poesia], culturais [como os diversos "centros de pesquisa"] e políticas [como o Movimento Negro Unificado]; e ações de mobilização política, de protesto antidiscriminatório, de aquilombamento, de rebeldia armada, de movimentos artísticos, literários e 'folclóricos' - toda essa complexa dinâmica, ostensiva ou encoberta, extemporânea ou cotidiana, constitui movimento negro.

${ }^{2}$ A Fundação Cultural Palmares foi criada em 22 de agosto de 1988. Segundo a instituição, na atualidade emitiu mais de 2.476 certificações para comunidades quilombolas. $O$ documento reconhece os direitos das comunidades quilombolas e dá acesso aos programas sociais do Governo Federal. É referência na promoção, fomento e preservação das manifestações culturais negras e no apoio e difusão da Lei 10.639/03, que torna obrigatório o ensino da História da África e Afro-brasileira nas escolas. A Fundação Palmares já distribuiu publicações que promovem, discutem e incentivam a preservação da cultura afrobrasileira e auxiliam professores e escolas na aplicação da Lei.
} 
cujo objetivo era explicitar uma posição crítica acerca das comemorações do centenário da abolição da escravidão. Segundo o teórico, utilizando carros de som, faixas e, fundamentalmente, os pulmões, os militantes pretendiam ir da Candelária até o monumento de Zumbi dos Palmares, na Praça Onze. Mas, não obtiveram êxito; foram impedidos pelo Exército em frente ao Comando Militar do Leste, mais especificamente, nas linhas do autor, um pouco antes do Panteão de Caxias. Dessa forma, Abreu (2005) afirma que mais de 600 soldados, armaram barricadas e ostentaram armas pesadas, impedindo a passagem da Marcha. Por último, Abreu assegura que os militantes não puderam passar em frente ao monumento de Caxias e por isso não chegaram, como pretendiam, ao monumento de Zumbi. Zumbi e Caxias, numa batalha metafórica no meio da Avenida Presidente Vargas.

Em vista disso, em 21 de março de 1988, sob decreto federal, Lei n. ${ }^{\circ} 7.668$, de 22 de agosto de 1988, foi criada a primeira instituição de recorte racial. Nesse sentido, José Sarney construiu um modelo de retórica que objetivava acalmar os ânimos da militância negra quanto aos problemas históricos de incorporação plena da população negra à nação.

Para tanto, o político buscou enaltecer a herança africana e o papel dócil ou passivo do negro, bem como procurou mitigar a denúncia feita pelos movimentos sociais negros nas marchas contra a comemoração do Centenário da Abolição (1988). Ele preferiu explicitar que aquele era um momento ímpar "para o reconhecimento e espírito de justiça"”, a exemplo das citações abaixo:

Se damos ao mundo - aprimorando a cada dia - a lição da convergência étnica e do congraçamento racial, isto se deve, na sua parte mais ampla, à postura do elemento negro nesse congraçamento e nessa convergência, superando conflitos, para sobrepairar a compenetração de que temos um papel a desempenhar, cada instante, na paz, na ordem e no desenvolvimento mundial (BRASIL, 1988).

O coração do Brasil não seria o mesmo sem a contribuição da cultura, da arte e da dança africanas. Nossa capacidade de superar a adversidade e nossa alegria provém, indubitavelmente, da Àfrica (BRASIL, 1988).

\footnotetext{
${ }^{3}$ Abertura das comemorações do centenário da abolição da escravatura. Palácio do Planalto 21 de março de 1988.
} 
Nesse ponto, refutando as "radicalidades" dos referidos movimentos e em prol da harmonia racial, José Sarney ${ }^{4}$ afirmou que o povo deveria se orgulhar de seu passado e, principalmente, da forma com que a "raça negra" fora adaptada ao território nacional. Essa lembrança associada pelo Presidente às contribuições da "raça negra" fez com que o país fosse uma nação singular, no qual cada componente seria vital à edificação da pátria, veja abaixo:

A população negra, que no passado defendeu, com o elemento branco e o elemento indígena, a nossa base física e a unidade nacional, tem também compromissos com o futuro do nosso Brasil, país a que está associado o seu sangue, o seu sonho, o seu orgulho, porque todos somos brasileiros (BRASIL, 1988).

A seu ver, a "sensibilidade criativa da raça negra" teria sido profícua ao nascimento da pátria. O autor do enunciado prosseguiu com a manutenção do argumento da conciliação racial ${ }^{5}$ :

Os atos que nesta hora se iniciam nos dão a oportunidade de declarar de público o nosso orgulho da raça negra. Daquela que aqui chegou com a sua cultura, com a sua sensibilidade criativa, e aqui se identificou com outras raças, na formação do povo brasileiro (BRASIL, 1988).

Ou seja, para o ex-Presidente, o Centenário da Abolição faria menção à libertação dos escravos pela Princesa Isabel, e, desse modo, teria sido pelas mãos do Estado que a condição dos negros africanos teria sido elevada. Em confluência na citação abaixo:

O Centenário da Abolição marca um compromisso da Nação brasileira consigo mesma. Valoriza a contribuição do negro na singularidade da vida brasileira. Essa singularidade se afirma a cada momento nas mais

\footnotetext{
4 José Ribamar Ferreira de Araújo Costa nasceu na cidade de Pinheiro, Maranhão, em 24 de abril de 1930. Formado em direito em 1954, ingressou na política como suplente do deputado federal pela UDN (União Democrática Nacional). Ingressou no PMDB (Partido do Movimento Democrático Brasileiro) e foi indicado como vice-Presidente na chapa de Tancredo Neves, pela Frente Liberal. Em virtude do falecimento de Tancredo, assumiu a presidência no dia 15 de abril de 1985. Disponível em: $<$ https://www.ebiografia.com/jose_sarney/>. Acesso em: 10/02/2016.

${ }^{5}$ A Lei n. ${ }^{\circ} 7.716 / 89$ conhecida como Lèi CAÓ de 5 de janeiro de 1989, em homenagem ao Deputado Carlos Alberto de Oliveira, destoava dos pronunciamentos pacíficos de José Sarney. De acordo com esta, é definido como crime o ato de praticar, induzir ou incitar a discriminação ou preconceito de raça, cor, etnia, religião ou procedência nacional. Também regulamentou o trecho da Constituição Federal que torna inafiançável e imprescritível o crime de racismo, após dizer que todos são iguais sem discriminação de qualquer natureza. Fato é que a referida lei tem sua origem um ano após o ato presidencial e apresenta contexto empírico distante da fala institucional.
} 
diversas expressões de nossa cultura. Afirma-se na dança, na música, no esporte, nas letras, na política, na ciência, na pintura, na escultura, na economia e nas relações sociais (BRASIL, 1988).

Esse formato de narrativa se relaciona com as formações discursivas que revisitam as histórias arqueológicas e buscam iluminar o passado com verdades, justamente porque as mesmas são móveis e deslocam-se ao longo dos discursos, bem como se debruçam sobre as práticas sociais, de modo a contornar os saberes procurando individualizar os enunciados discursivos.

Nesse aspecto, as colocações feitas por Sarney objetivam endossar interpretações monolíticas das causalidades sobre o fim do sistema escravista. A premissa se afina à perspectiva consensual e delineia um cenário de "liberdade instantânea" ao povo negro. Ademais, aponta para práticas sociais amistosas nascidas no cotidiano do brasileiro, o que por sua vez suavizaria as diferenças fenotípicas e a mácula da escravidão.

Neste eixo, o líder nacional se torna o portador dos acontecimentos históricos; a epistemologia verificada em seu discurso constrói a ciência, a racionalidade e, por conseguinte, a verdade. Doutro modo, José Sarney buscou o controle condicionado dos cidadãos a partir do discurso ajustado às "verdades já consagradas", ou mesmo, à formação de um passado idílico da pátria.

Em continuidade, o político procurou desconstruir a ideia de um projeto estatal difundido ao povo, ou seja, o calendário do Centenário da Abolição em 13 de maio deveria ser festejado a partir de outros aparelhos governamentais. E a dinâmica que orientava os movimentos negros era de luta contra data supracitada e redefinição dos heróis nacionais, conforme as Marchas Contra a Farsa da Abolição da Escravatura no dia 11 de maio, no Rio de Janeiro (1988), em frente ao Pantheon de Duque da Caxias, bem como a passeata em São Paulo no dia 13 de maio (1988), sob liderança do Movimento Negro Unificado (1988) contra a ideologia do mito da democracia racial. Hanchard (2001) assegura que a referida data era um festejo comemorativo típico das sociedades multirraciais, nas quais os grupos dominantes esticam a tela mítica da união nacional para fazê-la incluir imagens dos grupos subalternos; por sua vez, os grupos subordinados contestam os mitos de união nacional promovidos pelo Estado. 
Para Sarney, a data não ficaria circunscrita ao Governo; o ex-Presidente requisitou - Ministério da Cultura (MINC) para dialogar com setores militantes através de seminários, debates, conferências e publicações, compartilhando a ideia de parceria com diversos setores. Todo esse desenho revela a articulação com setores divergentes para proposição de uma democracia moderada.

Em termos pragmáticos, Sarney afirmou que todo apoio material se daria para tal proposta. Portanto, a sentença comprova que todo esse aparato discursivo era direcionado à comunidade negra, bem como competia com ela no cerne da agremiação dos movimentos sociais alinhados com a "identidade negra". Em linhas gerais, este percurso fomenta a hipótese quanto à nova fase do Brasil democrático, ou seja, naquele momento se estreitavam os rumos do tratamento da questão racial. Paralelamente, o ativismo da sociedade civil era um convite para participação política dos movimentos negros. Na fala do ex-Presidente:

Não cabe ao Estado brasileiro conduzir as comemorações do Centenário da Abolição da Escravatura como se detivesse ele a chave de interpretação da nossa história. Determinei ao Ministro da Cultura, Dr. Celso Furtado; que as comissões criadas para esse propósito funcionassem tão-somente como órgãos de apoio às próprias iniciativas da sociedade, à militância dos movimentos negros e aos projetos por eles mesmos propostos em todo o território nacional, em simpósios, debates, seminários, conferências, publicações e outras manifestações. Quando necessário, esse apoio será também material. E por isso estou abrindo um crédito especial para as comemorações (BRASIL, 1988).

Para finalizar, José Sarney declarou que teria criado a Fundação Palmares no intuito de apoiar "as inteligências e lideranças que se formassem na raça negra". E a partir dessa instrução poderiam atuar em todos os setores do Brasil, ratificando que, daquele momento em diante, se conceberiam "líderes" e "inteligências negras"6.

\footnotetext{
${ }^{6}$ A linha de raciocínio traçada pelo ex-Presidente José Sarney escamoteia o histórico e heterogeneidade dos movimentos negros brasileiros. Ou seja, desde meados do Século XV até o Século XIX, a historiografia alude à existência da resistência negra. De acordo com Petrônio Domingues (2006), a primeira etapa foi de 1889-1937, a segunda de 1945-1964 e a terceira fase de 1978-2000. À vista disso, se identificou a existência de associações, a imprensa negra e Frentes Negras em diferentes estados e atuações. Já nos anos 1940, podemos citar: o Teatro Experimental do Negro e a União dos Homens de Cor (SILVA, 2003). Adiante, entre os anos de 1940 e 1950, os Congressos do Negro foram realizados em São Paulo, Rio de Janeiro e Porto Alegre. Nesses congressos, as discussões giravam entorno da
} 
E sugeri e acordamos a criação de uma fundação que se chamará de Fundação Palmares, que irá apoiar as inteligências, as lideranças e as consciências que se formarem na raça negra no Brasil para que, dentro de poucos anos, nós tenhamos formado no País um contingente da raça negra que possa atuar em todos os setores do Brasil. Na linha dessa determinação acabei de assinar o decreto que declara monumento nacional a Serra da Barriga, em União dos Palmares, em Alagoas. Ali se deram as lutas lideradas por Zumbi, marco da conquista da liberdade dos negros escravos (BRASIL, 1988).

Doutra maneira, é como se antes a "raça negra" não estivesse apta para ocupar setores ou postos do governo, ou mesmo, a legitimidade dos movimentos negros só se faria com o remodelar dos seus atos políticos, ou mesmo, incorporação institucional.

Ao transcender acontecimentos históricos, identificamos que o Estado se antecede aos rumos que os movimentos negros iriam trilhar e à possibilidade de conflitos. Sob o prisma da governabilidade, se o descontentamento incitado pelos movimentos negros se ampliasse, o custo da tranquilidade poderia ser caro à ordem nacional, tendo em vista a possibilidade de desagregação do tecido social. Deste panorama da relação entre Estado e movimentos negros, se faz necessário o monitoramento histórico dessa prática, sobretudo pela atuação da militância e as chances de abertura política para o coletivo e assunção de sua agenda. E, de acordo com Hanchard:

quando um ativista assume essa responsabilidade, sua movimentação política é restringida pelas limitações e pelas tensões dinâmicas da relação entre o Estado e seus eleitores. Assim, esses mediadores não são meros representantes estatais ou ativistas em si, mas o resultado dialético da relação que dá origem à sua posição dentro do Estado (HANCHARD, 1994).

denúncia quanto à discriminação racial no Brasil e a necessidade de políticas públicas que vislumbrassem a cidadania da população negra (GOMES, 2012). No comparativo, na década de 1970, ocorre a ascensão do Movimento Negro Unificado, União dos Negros pela Igualdade (UNEGRO), Coletivo das Mulheres Negras e das Ongs Negras. Em decorrência desse fato, na esfera política, em meados de 1980, nascem as demandas por políticos negros no Parlamento. A exemplo de Abdias Nascimento, Benedita da Silva e Carlos Alberto de Oliveira. É nesse momento que Abdias Nascimento, através, de projeto ordinário, discurso, projeto de iniciativa interna, aprofunda o debate acerca da questão racial no Parlamento brasileiro e a traz à tona o tema da reparação, indenização e afirmação da identidade negra no Brasil (SANTANA, 2015). 
Neste sentido, as diretrizes da Fundação Palmares se adaptariam aos pedidos dos movimentos sociais negros. Conforme explicitado: "Estamos tomando as providências concretas para a desapropriação das terras, onde iremos erigir um marco ao Quilombo dos Palmares, reivindicação antiga dos movimentos negros do Brasil” (BRASIL, 1988).

No tocante à origem da Fundação Cultural Palmares, ela nasceu com enfoque na preservação da arte e cultura afro-brasileira e no ensino da História da África e afrobrasileira-brasileira nas escolas e, por último, reconhece os direitos das comunidades quilombolas no âmago da certificação e titulação de terras aos seus descendentes.

Cabe mencionar que a Fundação Palmares teve seu embrião em Uberaba (MG) em 1979. A militância negra promovia discussões sobre as formas de valorização da cultura afro-brasileira e, consequentemente, procurava elevar a autoestima da comunidade negra. Desse processo surgiu a Carta de Uberaba e a criação do Centro de Estudos AfroBrasileiros (CEAB), em Brasília. Foi nesse momento que se instituiu uma entidade dos movimentos negros no Distrito Federal e a Carta de Uberaba, bem como o documento foi inscrito nos Anais do Senado Federal, segundo a Fundação, por iniciativa do então senador Itamar Franco (1982).

Entretanto, anteriormente, segundo Amilcar Pereira (2010), em 1980, a Universidade Federal de Alagoas decidiu convidar um grupo de intelectuais e militantes negros para discutir a criação do Parque Nacional Zumbi dos Palmares. A ideia inicial era criar um projeto turístico, porém posteriormente se tornou um projeto político e ideológico. E dentre os intelectuais que participaram da criação desse monumento estavam: Abdias do Nascimento, Lélia Gonzalez e Joel Rufino dos Santos.

Em julho de 1981, Amilcar Pereira informou que Abdias do Nascimento apresentou um trabalho em nome do Conselho Deliberativo do Memorial Zumbi, na $33^{\circ}$ reunião da Sociedade Brasileira para o Progresso da Ciência (SBPC), em Salvador. Amilcar Pereira relatou que na ocasião, Abdias do Nascimento denunciava a tentativa de folclorização da 
Nacional sobre o Quilombo de Palmares, em Alagoas (1982), sob a unificação dos

movimentos negros com o Movimento Negro Unificado. Além disso, a Convenção

Nacional do Negro (1986) confeccionou uma carta de demandas a serem discutidas na

Assembleia Constituinte de 1988. Nesse documento a questão dos remanescentes de quilombos está assegurada na súmula IX, artigo $2^{\circ}$, "Será garantido título de propriedade

7 Outro marco, à época, foi o resgate simbólico de Zumbi dos Palmares, de acordo com a Fundação, entre 1979 e 1989. No dia 20 de novembro, realizou-se uma peregrinação à Serra da Barriga, em Alagoas, no município de União dos Palmares, com vistas a homenagear o líder Zumbi dos Palmares. Nesse encontro estiveram presentes: Mãe Hilda, Abdias do Nascimento, o reitor da UFAL, João Azevedo, e dos movimentos negros, representado pela Associação Cultural Zumbi, sob a coordenação do Zezito Araújo, e a colaboração de Fátima, Wanda e Silvete. Igualmente, participaram da peregrinação aliados indígenas e outros grupos de militância negra: o Floresta Aurora, em Porto Alegre/RS, o Elite Clube e a Frente Nacional Afro-Brasileira (Fenabra), em Uberaba/MG, o llê Ayê e o Olodum, em Salvador/BA, o Centro de Cultura Negra (CCN), em São Luiz/MA. O Centro de Defesa do Negro (Cendenpa), em Belém/PA, o Instituto de Pesquisas da Cultura Negra (IPCN), no Rio de Janeiro/RJ, o Centro de Estudos AfroBrasileiros (CEAB), em Brasília, líderes dos encontros de negros do Norte e Nordeste, bispos e padres católicos, mães e pais-de-santo, todos unidos na corrente negra da reafirmação da marcante presença de africanos e afro-brasileiros na formação da nacionalidade. Assim como artistas: Milton Gonçalves, Gilberto Gil, Zezé Mota, Paulinho da Viola, Martinho da Vila e o Grupo União e Consciência Negra (Grucon), formado por militantes negros católicos, que nasceu nos anos 1970. Nas observações do exPresidente da instituição, Carlos Moura, "trata-se da entidade que precedeu a Pastoral Afro-Brasileira" (BRASIL, FUNDAÇÃO PALMARES, 2008, p. 10). Em continuação, em 1988, nos 100 anos da Lei Áurea, o Presidente da República José Sarney consagrou a Serra da Barriga Patrimônio Nacional e desapropriou as terras onde existiu o Quilombo dos Palmares, de acordo com os relatos de Carlos Moura. E nos dias 26 e 27 de agosto de 1987, militantes dos movimentos negros reuniram-se em Brasília no encontro "O Negro e a Constituinte". As conclusões foram encaminhadas a diversos parlamentares e ao Presidente da República, no dia 3 de setembro. Segundo informe da instituição, Carlos Moura, ao lado de Maria Luiza Junior, Lauro Lima Filho e outros, abordaram a proximidade do Centenário da Lei Áurea e sugeriram a criação de um órgão cultural, no Ministério da Cultura, com o objetivo de tratar da valorização cultural afro-brasileira. Cabe pontuar que a criação da Fundação Palmares passou pela aprovação da Câmara dos Deputados. Para Carlos Moura houve forte pressão da militância negra dentro e fora dos quadros governamentais, a exemplo da participação de Benedita da Silva, Paulo Paim, Edmilson Valentim, Carlos Alberto de Oliveira Caó e Abdias do Nascimento, para aprovação da instituição na Constituinte de 1988. Carlos Moura declarou que, sancionada a lei de criação da Fundação Cultural Palmares, foram suscitadas novas dificuldades para o decreto dos estatutos, já então partidas de setores do Ministério da Administração. Segundo alegações do ex-Presidente da Fundação, Carlos Moura, a entidade não possuía quadro de pessoal e o decreto determinava que, além dos cargos de confiança, o preenchimento das vagas seria feito mediante solicitação do servidor interessado (BRASIL, FUNDAÇÃO PALMARES, 2008, p. 16). Sendo assim, publicada a portaria da FCP, se estabeleceu que só se poderia investir no cargo a partir de concursos públicos, em concordância com a Constituição Federal, de acordo com Carlos Moura: "Buscava-se uma filigrana administrativa para impedir o funcionamento da instituição afro-brasileira” (BRASII, FUNDAÇÃO PALMARES, 2008, p. 16). 
de terra às comunidades negras remanescentes de quilombos, quer no meio urbano ou rural" 8 .

Quanto ao inciso terceiro da Fundação Palmares, este propunha a identificação das comunidades dos quilombos, o reconhecimento, a delimitação e demarcação de terras e, posterior, titulação. A complicação reside no litígio lento e conflituoso entre quilombolas, a iniciativa privada e estatal. ${ }^{9}$ As terras em disputa são requisitadas por proprietários rurais, empresários e pela Marinha do Brasil.

Segundo Mattos (2012), no caso dos processos judiciais mobilizados pelos militares, se destaca a questão da defesa nacional e as possíveis áreas vitais para os exercícios de adestramento militar e de viés estratégico, de acordo com a Marinha do Brasil. A exemplo da Base de Alcântara, território em disputa entre a Marinha do Brasil e os remanescentes de quilombos, onde está alocado o Centro de Lançamento de foguetes. É oportuno explicitar que o território predito, na atualidade, é requisitado também pelos Estados Unidos devido à localização estratégica para o lançamento de foguetes.

${ }^{8} \mathrm{~A}$ convenção predita congregou as seguintes organizações dos movimentos negros: Centro de Estudos e Defesa do Negro do Pará (CEDENPA), Centro de Cultura Negra do Maranhão (CCN), Comissão Próassociação do Conselho Nacional do Direito da Mulher, Movimento Negro Unificado (MNU/PE), Fundação Afro-brasileira (FUNDABRAS), Casa da Cultura Afro-Sergipana (CCAS), Federação dos Cultos Afro-brasileiros e Umbanda de Sergipe (FCABUS), União dos Negros de Sergipe (UNA), Associação dos Moradores de Aracaju (AMANOVA), Grupo Negro Filho de Zambi, Movimento Negro Unificado (BA), Sociedade Comunitária OJÚ-OBA, Bloco Afro Muzenza, Bloco Afro Orunmilá, Afoxé Ojú-obá, Conselho das entidades negras, Movimento Negro Unificado (MG), Frações dos movimentos negros do PCB e outras entidades dos movimentos negros.

${ }^{9}$ Convém dizer que os grupos étnicos autodeclarados quilombolas constituem as famílias que mantêm práticas tradicionais e possuem formas específicas de uso dos recursos naturais como a prática do sistema de uso comum; se orientam por uma temporalidade ordenada por calendários de festas religiosas; suas territorialidades são orientadas pela crença em seres míticos; e, inclusive, em algumas situações, possuem nas suas terras as denominadas "provas materiais", tão valorizadas por objetivistas, como poços antigos, sumidouros, restos de antigas fazendas, ruínas de engenhos, árvores e matas chamadas de matas velhas, enfim, uma série de vestígios materiais que atestam a ancestralidade das terras. Entretanto, apesar dessa variedade de situações, um dos elementos que os faz acionarem o dado étnico como de pertencimento é o critério político organizativo. $O$ étnico não está circunscrito a uma língua comum, a uma ancestralidade, a uma origem comum e sim a uma forma de mobilização que "expressam formas de agrupamento político em torno de elementos comuns" (ARRUTI, 1997). Contudo, a categoria quilombo, quando acionada como "categoria nativa" abarca situações exclusivas, que marcam uma diferenciação em relação ao modelo oficial proposto via políticas governamentais como a noção de loteamento das áreas; individualização dos recursos naturais; mercantilização do sistema de saúde; formalização dos sistemas de representação e delegação, dentre outros. Em linhas gerais, quilombo é uma categoria que foi incorporada aos discursos dos agentes sociais em função de suas práticas e, comporta, nessas situações, um elenco de representações sociais (ALMEIDA, 2010). 
Ademais, predomina o discurso quanto a esses territórios serem constituídos de jazidas minerais cruciais para o desenvolvimento econômico, desse modo, pauta de segurança nacional. Outrossim, o argumento militar descortinou o interesse das ONGs estrangeiras nas terras em disputa, as quais sustentariam o argumento de proteção das minorias etnicorraciais para encobrir seus objetivos. Por último, Mattos afirma que essas áreas estão localizadas em reservas de Mata Atlântica estando, por isso, protegidas por uma série de dispositivos legais, como o exemplo da Constituição Federal, a qual dispõe em seu art. 225:

Art. 225. Todos têm direito ao meio ambiente ecologicamente equilibrado, bem de uso comum do povo e essencial à sadia qualidade de vida, impondo-se ao Poder Público e à coletividade o dever de defendê-lo e preservá-lo para as presentes e futuras gerações. $\S 4^{\circ}$. A Floresta Amazônica brasileira, a Mata Atlântica, a Serra do Mar, o Pantanal MatoGrossense e a Zona Costeira são patrimônio nacional, e sua utilização farse-á, na forma da lei, dentro de condições que assegurem a preservação do meio ambiente, inclusive quanto ao uso dos recursos naturais (MATTOS, 2012, p. 42).

Ainda na base das contestações, se assinala que a Constituição Estadual do Rio de Janeiro, em seus artigos 268 e 270, preceitua:

Art. 268. São áreas de preservação permanente: IV- as áreas que abriguem exemplares ameaçados de extinção, raros, vulneráveis ou menos conhecidos, na fauna e flora, bem como aquelas que sirvam como local de Pouso, alimentação ou reprodução; V- as áreas de interesse arqueológico, histórico, científico, paisagístico e cultura; Art. 270 - As terras públicas ou devolutas, consideradas de interesse para a proteção ambiental, não poderão ser transferidas a particulares a qualquer título (MATTOS, 2012, p. 43).

No entanto, de acordo com Mattos (2012, p. 24), na década de 1990, a então Senadora Benedita da Silva propôs um projeto de lei regulamentando o Art. 68 dos Atos das Disposições Constitucionais Transitórias (ADCT). Tal projeto deu início a discussões relacionadas com a autoatribuição de raça, origem e de território a ser reivindicado por comunidades ditas quilombolas, além de atribuir aos órgãos do Governo a responsabilidade pela condução dos processos relativos à causa. O projeto foi aprovado pelo Congresso Nacional e remetido para sanção presidencial que sofreu o veto do 
Presidente Fernando Henrique Cardoso (1995-2003). O veto foi submetido ao Legislativo que, da mesma forma, o ratificou.

Em última análise, o Projeto de Lei criado pela Senadora Benedita da Silva remetia à proposição da autodeclaração do remanescente de quilombo fora das terras em questão e atribuía mais setores do governo no processo de identificação, demarcação e titulação das terras em litígio. De todo modo, descortinamos a disputa entre o Poder Legislativo, Judiciário e Executivo, ou seja, o grau de interlocução entre as instituições mediadoras do conflito. De um lado, o Legislativo composto, parcialmente, de proprietários rurais. De outro, o embate quanto à proposição da Senadora e a desatualização do artigo 68 do Ato das Disposições Constitucionais Transitórias, à mercê da interpretação do Poder Judiciário, bem como a aprovação final do Executivo.

Todavia, conforme informou Mattos (2012, p. 24), em 2003, com a assunção do Presidente Luís Inácio Lula, houve a assinatura do Decreto 4.887, de 20 de novembro de 2003, revogando o anterior e recuperando todas as considerações contidas no projeto da Senadora Benedita e que haviam sido rejeitadas anteriormente. Esse Decreto, portanto, é o que regulamenta o procedimento para identificação, reconhecimento, delimitação, demarcação e titulação das terras ocupadas por remanescentes das comunidades de quilombos conforme o art. 68 do ADCT. Segundo o decreto, o Incra, a Fundação Cultural Palmares, o IBAMA, a FUNAI, a Secretaria-Executiva do Conselho de Defesa Nacional agiriam em conjunto conciliando os interesses do Estado .

Outro fato relevante reside no lançamento, em 2004, do Programa Brasil Quilombola que agrupa as ações voltadas às comunidades nos eixos: Acesso à Terra; Infraestrutura e Qualidade de Vida; Inclusão Produtiva e Desenvolvimento Local; e Direitos e Cidadania, sob Decreto n. 6.261 , de 20 de novembro de 2007. Junto a esse programa foi aplicada a concessão de crédito rural ao pequeno agricultor para financiamento agrário, em meio às propostas de desenvolvimento sustentável do Programa Nacional da Agricultura Familiar (Pronaf). ${ }^{10}$ Essa medida pareceu contornar as

\footnotetext{
${ }^{10}$ O Programa Nacional de Fortalecimento da Agricultura Familiar (Pronaf) destina-se a estimular a geração de renda e melhorar o uso da mão de obra familiar, por meio do financiamento de atividades e serviços rurais agropecuários e não agropecuários desenvolvidos em estabelecimento rural ou em áreas comunitárias próximas.
} 
No que diz respeito ao processo para reconhecimento das terras, a lei estipula que cabe à União a indenização aos seus “possíveis donos” para prosseguir com a titulação das terras de quilombo. Neste viés, o processo de titulação percorre inúmeros obstáculos para sua efetividade. Desde a aferição da identidade quilombola pela Fundação Palmares e pelo Incra; delimitação das terras, espera pela reclamação da área em litígio, indenização, demarcação do território reconhecido e, por último, a entrega do título. $\mathrm{Na}$ prática, a lentidão com que se processam esses atos tornam a legislação inócua.

Por fim, as ações recorrentes têm sido a titulação provisória das terras quilombolas. Em decorrência desse princípio normativo, aventamos que o gerenciamento da Fundação Palmares dependia também da liderança empossada, e esta deveria estar ajustada ao Estado. Outro dado pertinente recai sobre o termo remanescente quilombola. Este foi objeto de protesto pelo Ministério da Cultura e pela militância negra, porque a nomenclatura "remanescentes das comunidades dos quilombos" destoa da realidade atual dos quilombolas, ou seja, haveria quilombolas dispersos pelo território nacional, principalmente nos centros urbanos e, por isso, não abarcados pela lei que entendia que os beneficiários deveriam ser aqueles residentes em áreas rurais.

Nesse caso, a nova interpretação inferiu que estariam garantidos os direitos individuais e não coletivos dos quilombolas, o que demonstrou a incapacidade quanto à aplicação da referida lei no quesito redistribuição de terras, tendo em vista o erro político e interpretativo feito pelo Estado na redação da lei em debate. Em última análise, a lei deveria abarcar os direitos coletivos e não individuais em sentido atemporal.

Os movimentos sociais quilombolas, segundo a Convenção Nacional do Negro (1986), visavam a titulação da propriedade de terra às comunidades negras remanescentes de quilombos, quer no meio urbano ou rural e atemporal, segundo a 
Coordenação Nacional de Articulação das Comunidades Negras Rurais Quilombolas (CONAQ) $)^{11}$.

Em última instância, quatorze anos depois, o Poder Executivo examinou que as comunidades de quilombolas, denominadas "Terras de Preto", "Comunidades Negras Rurais", "Mocambos" ou "Quilombos", podem ter migrado para outras áreas e até contextos urbanos, o que não inviabilizaria a demarcação de terras dos grupos etnicorraciais requisitantes da referida lei na atualidade. Conforme explicitado neste trecho:

Conclui-se, portanto, que o constituinte de 1988 visou a beneficiar tãosomente os moradores dos quilombos que viviam, até 1888 , nas terras sobre as quais estavam localizadas aquelas comunidades, e que continuaram a ocupá-las, ou os seus remanescentes, após o citado ano até 5 de outubro de 1988 .De fato, a emissão dos títulos de propriedade, que é, por imposição do art. 68 do $\mathrm{ADCT}$, dever do Estado, deve favorecer, ainda segundo esse mesmo artigo constitucional, os remanescentes das comunidades dos quilombos e não as comunidades remanescentes dos quilombos. Repita-se: o direito de propriedade foi reconhecido pela Constituição àqueles e não a estas. Daí a violação dos arts. 11 a 15 do projeto ao art. 68 do ADCT (BRASIL, 2003).

Outro ponto relevante para análise recai sobre os problemas direcionados à Fundação Palmares quanto à sua jurisdição. De acordo com Carvalho (2016), a instituição emitiu a portaria (n. $\left.{ }^{\circ} 25\right)$ que estabelecia as normas para trabalhos e identificação das terras a serem ocupadas por comunidades remanescentes de quilombos. Todavia, 0 Instituto Nacional de Colonização e Reforma Agrária, (INCRA) autarquia do Ministério do Desenvolvimento Agrário (MDA), emitiu a portaria n. 307 que possibilitava a demarcação de terras, a medição e a titulação das terras quilombolas inseridas em áreas públicas federais.

Fato é que a Fundação Cultural Palmares pareceu não corresponder às expectativas dos movimentos negros visto que, em dezembro de 2002, a Coordenação

\footnotetext{
${ }^{11}$ No ano de 1996, durante uma seção de Avaliação do "I Encontro Nacional de Comunidades Negras Rurais Quilombolas", realizado na Bahia, surge a CONAQ, que substituiu a comissão provisória das comunidades negras rurais quilombolas. A CONAQ teve "como caráter central se constituir como movimento social, não se configurando como outras formas organizativas tais como organizações não governamentais, sindicatos ou partidos políticos" (SOUZA, 2000, p. 14).
} 
Fundação de origem no decreto $n .^{\circ}$ 3.912/2001 e pleiteava a criação de uma Secretaria Nacional de Quilombos.

De todo modo, a Fundação Cultural Palmares, o Incra e a Secretaria Especial de Políticas de Promoção da Igualdade Racial (SEPPIR), em conjunto, deliberaram sobre as etapas de identificação, reconhecimento, delimitação, demarcação e titulação das terras ocupadas por remanescentes das comunidades dos quilombos. E o Incra estipulou que o relatório técnico dos antropólogos seria fundamental para a legitimidade do processo. Ainda que a autodeclaração fosse parte do laudo técnico, este dispositivo suscitou animosidades nos movimentos negros, tendo em vista o questionamento da legitimidade da autodeclaração dos requisitantes. Por conta dos possíveis casos de fraude e pela sustentação do árbitro quanto à autoidentificação passar pelo filtro estatal. Na percepção de Carvalho:

Muitos representantes das comunidades dos quilombos que participaram do Grupo de Trabalho Interministerial que elaborou a minuta do referido decreto entendiam que, na medida em que a caracterização de tais coletividades passaria da comprovação de uma ocupação centenária à autodefinição, o relatório antropológico não era necessário e que se fosse colocado como peça técnica obrigatória poderia representar um entrave aos processos de regularização fundiária desses grupos (CARVALHO, 2016, p.115).

De todo modo, o Incra optou por maior rigor na análise técnica do relatório antropológico, os processos judiciais contrários a autodefinição dos quilombolas e suas terras. Assim como, o processo ajuizado pelo Partido Frente Liberal, atual Democratas, Ação Direta de Inconstitucionalidade n..$^{\circ} 323$, se avolumaram e as refutações à desapropriação das terras produtivas e os critérios de definição dos territórios quilombolas. Partindo estas objeções, o Incra estipulou que:

Ele deveria conter introdução aos conceitos e metodologia empregados; dados gerais sobre o município e o grupo; histórico da ocupação; organização social; dados sobre ambiente e produção e conclusão. Esses seis itens são desdobrados num total de 35 subitens bastante específicos. 
Estabeleceu-se também que ele deveria ser feito, preferencialmente, por servidores do Incra, vedando a participação de pesquisadores que já tivessem assessorado as comunidades objeto de reconhecimento (CARVALHO, 2016, p. 137).

E a partir do decreto . $^{\circ} 4.887$, de 20 de novembro ${ }^{12}$ de 2003 , em seu Art. $2^{\circ}$ ficou definido que: "Consideram-se remanescentes das comunidades dos quilombos, para os fins deste Decreto, os grupos étnicorraciais, segundo critérios de auto atribuição, com trajetória histórica própria, dotados de relações territoriais específicas, com presunção de ancestralidade negra relacionada com a resistência à opressão histórica sofrida. De acordo com $\S 1^{\circ}$ “Para os fins deste Decreto, a caracterização dos remanescentes das comunidades dos quilombos será atestada mediante auto definição da própria comunidade".

Em breves linhas, algumas concessões foram feitas aos movimentos negros e quilombolas, bem como entendemos que a redistribuição das terras devolutas pela União se constitui processos morosos. Em continuação, o fulcro do duelo entre o Incra e a Fundação Cultural Palmares evidenciou que o Governo Federal mediou as duas autarquias com a finalidade mitigar as próprias incoerências, ou seja, incompletudes dos objetivos da instituição.

Em outras palavras, delineou o grau de interlocução entre as esferas governamentais comprovando as divergências entre as instituições políticas que acomodaram a questão, bem como identificou os principais embates fomentados pela agenda racial em termos nacionais. Vale frisar que a militância negra se colocou de maneira autônoma diante dos entraves para implementação das suas requisições.

Este fato por ser evidenciado ao examinarmos as críticas dos coletivos remanescentes de quilombos às ações da Fundação Cultural Palmares e o pedido de transferência das funções de identificação, remarcação e titulação de terras para o Incra.

\footnotetext{
${ }^{12}$ Cabe explicitar que a data 20 de novembro foi iniciativa do Grupo Palmares (1971) de Porto Alegre contra o marco oficial da República dia 13 de maio. A ideia dos militantes negros era trazer a rememoração dos líderes negros da história brasileira e, com isso a conscientização da população. Noutros termos, o Grupo Palmares reivindicava o conhecimento do passado dos povos africanos para promover uma integração "consciente", o que garantiria a fuga da alienação proposta pelo 13 de maio e suas representações (CAMPOS, 2006).
} 
O objetivo do presente Projeto de lei é, por isso mesmo, repita-se, cumprir o que dispõe a Constituição Federal, titulando-se definitivamente os remanescentes das comunidades dos quilombos como efetivos proprietários de suas terras sem delongas, postergações ou formalismos. Essa uma das razões pela qual prescindiu-se da transição do título de propriedade no Registro de Imóveis para produzir efeitos erga omnes. ${ }^{13}$

Em síntese, podemos compreender a gênese, os objetivos da Fundação Palmares e seu aperfeiçoamento como fruto da militância negra nos quadros institucionais. Adiante, observaremos as narrativas do Presidente Fernando Henrique em relação ao tema da raça em meio a marcha dos movimentos negros (1995).

\section{Fernando Henrique Cardoso (1995-2003) e o tom ambíguo à agenda racial}

De acordo com Santos (2005), após o reconhecimento da existência do racismo no país pela via estatal, em 1995, houve um alinhamento concernente à luta pela sua eliminação e influenciado pela mobilização do movimento negro, colocou essa temática sob novas perspectivas no cenário nacional.

Entretanto, para Santos, foi a Conferência de Durban que simbolizou uma oportunidade de pressionar tanto nacional quanto internacionalmente a tomada de decisões e ações concretas que viessem a eliminar as desigualdades raciais. Seguindo o processo de preparação para a Conferência, foi lançado no dia 08 de setembro de 2000 um Decreto pelo presidente Fernando Henrique Cardoso que estabelecia a constituição do Comitê Nacional. Naquele momento, sob a presidência, na ocasião, do Secretário de Estado Direitos Humanos, Embaixador Gilberto Sabóia, que procurou abarcar todas as representações que pretendiam participar na Conferência.

Assim, segundo Santos, em setembro de 2000, em São Paulo, foi lançado o Comitê Impulsor que tinha por objetivo potencializar a participação de um maior número possível de entidades negras na Conferência de Durban, principalmente de organizações do movimento negro.

\footnotetext{
${ }^{13}$ Mensagem n. ${ }^{\circ}$ 370, 13 de maio de 2002.
} 
Anteriormente, em 20 de novembro de 1995, a militância negra promoveu a Marcha em Comemoração à Zumbi dos Palmares (1995). Segundo Ribeiro (2008), em 20 de novembro, Brasília, em parceria com outros setores da sociedade - a Marcha Zumbi dos Palmares contra o Racismo, pela Cidadania e pela Vida, que reuniu cerca de 30 mil manifestantes. Em ato oficial, por meio da coordenação da Marcha, foi entregue ao Presidente da República, Fernando Henrique Cardoso, o Programa de Superação do Racismo e da Desigualdade Racial, o qual apresentava uma série de reivindicações visando à inclusão da população negra nas políticas públicas, com destaque para o mercado de trabalho, a educação, a cultura e a comunicação, a saúde, o combate à violência, a religião e a terra.

Em resposta a este evento a Presidência da República, sob o comando de Fernando Henrique Cardoso, se reportou aos protestos negros de forma criativa e pacificadora quanto às petições de fundamentação racial.

E, em 20 de novembro de 1995, ao criar o Grupo de Trabalho Interministerial para Valorização da População Negra no Palácio do Planalto, o Presidente Fernando Henrique Cardoso assumiu o compromisso de dialogar com os movimentos negros do Brasil (BRASII, 1998). ${ }^{14}$

Naquele momento, o líder político, ao lado da ex-Senadora Benedita da Silva, participou da comemoração aos 300 anos de Zumbi dos Palmares. Além disso, declarou que estivera na União dos Palmares, reconheceu a importância do panteão dos heróis nacionais, a exemplo de Zumbi. Por fim, identificou neste um ícone lutador pela liberdade. Em seus termos:

Nesta manhã, acompanhado pela senadora Benedita da Silva e pelos ministros da Educação, da Cultura e dos Esportes, estivemos em União dos Palmares para que ficasse bem claro que o Governo, pelo Presidente

\footnotetext{
${ }^{14}$ Este conceito norteou a elaboração das medidas que viessem a corroborar com o enfrentamento do racismo, porém, esse primeiro passo, em direção a uma política de ação afirmativa para a população negra, não se concretizou como o esperado. As medidas elencadas pelo GTI estavam distantes das aspirações do movimento negro e, no que tange a sua organização enquanto uma política pública, o que se observou foram uma fragmentação e uma não institucionalização em termos de corpus político e técnico-operativo. $O$ que ocorreram foram medidas isoladas que não conseguiram atingir o cerne da questão (WERNECK, 2005). WERNECK, J.. A luta continua: O combate ao racismo no Brasil pós-Durban. Revista do Observatório da Cidadania, n. 55, 2005. Disponível em: . Acesso em: 01 jun. 2007.
} 
da República, assumia Zumbi como integrante do panteão dos heróis brasileiros, Zumbi, como símbolo de um lutador pela liberdade. (CARDOSO, 1996)

Em consonância, ao reconhecer Zumbi dos Palmares como herói nacional, trouxe à esfera institucional a petição dos movimentos negros deste a Frente Negra Brasileira (1931) e o Movimento Negro Unificado (1978), qual seja, a valorização da resistência negra conferida na construção dos quilombos, bem como a aclamação dos ícones da identidade negra.

Contudo, importa destacar que a autora desta criação foi a então Deputada Benedita da Silva (PT/RJ) a partir do Projeto de Lei $n^{\circ} 1.911 / 1996$, por ocasião do tricentenário da morte de Zumbi dos Palmares. Ainda neste escopo, o episódio narrado pelo ex-Presidente não explicitou as origens políticas dos marcos simbólicos, bem como as iniciativas de militantes negros no campo político.

Proporcionalmente, em seu discurso buscou atrelar sua trajetória acadêmica até a sua posição política para promoção da igualdade racial. Desse modo, ao longo do discurso elencou ações empíricas que denotariam seu esforço em torno da pauta racial. Nas suas palavras:

Sou comprometido pessoalmente com os estudos da questão negra no Brasil. Escrevi dois livros sobre a matéria, na época em que se mantinha a ideia de que, no Brasil, não havia um problema negro e que não havia discriminação racial. Com o professor Florestan Fernandes e com Otávio lanni, sob a inspiração de Roger Bastide, fizemos pesquisas que mostraram o oposto: havia preconceito, havia discriminação. E para que pudesse se concretizar o ideal de democratização do Brasil implicaria que os que lutam pela democracia e pela liberdade, assumissem também a luta em favor da igualdade racial. (BRASIL, 1998)

Fernando Henrique buscou na equivalência entre os termos, "democracia", “cidadania", “tolerância" e "luta afirmativa" para defender seu ponto de vista concernente aos extremismos de valorização da raça, como se os movimentos negros pudessem produzir uma ferramenta de opressão aos brancos. Sob sua análise:

Acredito que hoje temos condições de ampliar as instâncias nas quais esses temas serão debatidos. Sempre dentro da perspectiva democrática, sempre dentro da perspectiva da tolerância. Não aceitando nenhuma forma de racismo, nem mesmo o racismo para valorizar a raça que está sendo discriminada porque isso resulta também numa coisa 
negativa. Tem que ser uma posição afirmativa e não de negação da existência de diferenças e discriminações. Tudo isso dentro de uma perspectiva, como disse o Professor Hélio Santos, de cidadania e de democracia. (BRASIL, 1998)

O ex-Presidente postulou que o caminho para resolução do racismo no país passaria pelo diálogo entre governo e sociedade. Ao destacarmos este enunciado, subjacente ao caminho proposto pelo ex-Presidente está em voga a redução do papel desempenhado pelo Estado para diluição das desigualdades sociais, ou seja, às claras esteve a descontinuidade do Estado-providência e a proposição da gestão das problemáticas raciais através da parceria estatal com a sociedade.

Em suas palavras: "Não tenhamos ilusões. Não se resolve isso de um momento para o outro porque é um problema cultural, e é um problema social. Não é um problema que o Governo resolva sozinho. A sociedade, junto com o governo, tem que resolver" (BRASIL, 1998).

Em comparação, em 2 de julho de 1996, ocorreu no Palácio do Planalto o Seminário Internacional "Multiculturalismo e Racismo: o papel da ação afirmativa nos estados democráticos contemporâneos". Neste evento, o ex-Presidente enfatizou a perspectiva multirracial da sociedade brasileira, bem como afirmou haver preconceito racial no país ${ }^{15}$. Neste âmbito, o político deslocou o conceito de multirracial para

15 Neste eixo, assim como José Sarney, o ex-Presidente Fernando Henrique Cardoso escondeu a peculiaridade do racismo no Brasil, ou seja, o racismo à brasileira. Este residiria na negação da existência do racismo relativo à pretos e pardos, bem como refutaria qualquer argumento concernente a assimetria social entre brancos e não-brancos. Assim como, a raiz histórica da colonização encontraria narrativa voltada à confluência biológica, em meio experiências cotidianas amistosas entre raças distintas. $O$ que para ambos os estadistas não teria se configurado em contextos alhures. Por exemplo, as leis Jim Crow (1876-1965) de segregação racial entre brancos e não-brancos nos Estados Unidos, em semelhança ao apartheid racial na África do Sul. Neste sentido, tanto José Sarney, quanto Fernando Henrique Cardoso prevalecem destes dados com intuito de minorar o dilema brasileiro. Cabe mencionar que as leis segregacionistas foram embasadas nas teorias racialistas, quanto à existência de raças inferiores e superiores, bem como se reportavam aos perigos da mestiçagem entre os tipos raciais diferenciados. À época, estas ideias acolhidas pelo pensamento social brasileiro, foram contrapostas pelos escritos de Gilberto Freyre (1900-1989), os quais acomodavam a leitura "açucarada" do caldeamento brasileiro. Se contrapondo às publicações pessimistas de Nina Rodrigues, Paulo Prado e Edgar Roquete Pinto. Concomitantemente, a perspectiva do branqueamento brasileiro com a introdução do imigrante branco pela via estatal, contornaria a mácula do sangue africano e, desse modo, seria a profilaxia para o desenvolvimento econômico e social nacional. Parafraseando o diagnóstico suscitado por Oliveira Viana (1956). Em linhas gerais, os políticos preditos exaltaram o histórico da formação brasileira com vistas ao não-enfrentamento do racismo. Em paralelo, pincelaram dados oficiais e ideológicos que corroboravam à afirmação da singularidade brasileira, em objeção a realidade da iniquidade racial que paira sobre o povo negro (MUNANGA, 1999). 
exemplificar os efeitos da miscigenação sobre a população, descaracterizando, portanto, qualquer ação de fulcro identitário. Haja vista, sob sua análise, a complexidade da formação cultural da nação.

Por isso, nas soluções para esses problemas não devemos simplesmente imitar. Temos que usar a criatividade. A nossa ambiguidade, as características não cartesianas do Brasil, que dificultam em tantos aspectos também podem ajudar em outros. Devemos buscar soluções que não sejam pura e simplesmente a repetição, a cópia de soluções imaginadas para situações onde também há discriminação, onde também há preconceito, mas num contexto diferente do nosso. É melhor, portanto, buscarmos uma solução mais imaginativa. (CARDOSO, 1996)

Simetricamente, em 27 de fevereiro de 1996, no Palácio do Planalto, houve a comemoração do Grupo Interministerial da População Negra. Em analogia a Freyre, Fernando Henrique retomou a perspectiva de "antagonismos equilibrados", ou seja, as ambiguidades entre negros e brancos que se desenrolam nas práticas culturais e sociais, não deveriam promover cisões de ordem bipolar na sociedade brasileira. ${ }^{16}$ Sob sua assertiva:

Não devemos, não obstante, exagerar nessa crítica e autocrítica. Se é verdade que existe um lado de hipocrisia, há outro lado que é de abertura. Convivemos com essa ambiguidade na nossa formação cultural. E é preciso tirar o proveito dessa ambiguidade. Não sei se será por temperamento, mas não gosto das coisas muito cartesianas. Acho que as coisas mais ambíguas são melhores. Quando não existe muita clareza, talvez seja mais fácil. Muitas vezes a clareza separa demais. (CARDOSO, 1996, p.8)

\footnotetext{
${ }^{16}$ No cerne da discussão sobre democracia racial, de acordo com Gomes (2005), o mito da democracia racial pode ser compreendido, então, como uma corrente ideológica que pretende negar a desigualdade racial entre brancos e negros no Brasil como fruto do racismo, afirmando que existe entre estes dois grupos raciais uma situação de igualdade de oportunidade e de tratamento. Esse mito pretende, de um lado, negar a discriminação racial contra os negros no Brasil, e, de outro lado, perpetuar estereótipos, preconceitos e discriminações construídos sobre esse grupo racial. Dessa forma, Gomes adverte que o mito da democracia racial atua como um campo fértil para a perpetuação de estereótipos sobre os negros, negando o racismo no Brasil, mas, simultaneamente, reforçando as discriminações e desigualdades raciais ou é inferior ou é maléfico (religião, ritmos, hábitos, etc). Em consonância, para Gomes, o Brasil, enquanto uma nação "mestiça", resultante, entre outras coisas, dos contatos e intercursos sexuais entre o português e as mulheres negras e indígenas, construiu-se alicerçado na violência sexual contra essas mulheres e não somente em relacionamentos amistosos entre as raças. Sendo assim, podemos dizer que Casa-Grande e Senzala (1933) apresenta a humanidade e as relações sociais e raciais sob a ótica do senhor patriarcal. GOMES, Nilma Lino. Alguns termos e conceitos presentes no debate sobre relações raciais no Brasil: uma breve discussão. In: Brasil. Educação Antiracista: caminhos abertos pela Lei federal n. 10.639/03. Brasília, MEC, Secretaria de educação continuada e alfabetização e diversidade, 2005, P.39- 62.
} 
Neste aspecto, para o político, tais diferenças não poderiam ser vetor de formulação de uma agenda focal de fundo racial, ou mesmo, para promoção de “privilégios”. Em suas palavras:

Eis aí, realmente, uma ameaça para a civilização contemporânea. É por esse tipo de apelo, que é irracional, que nós aqui fazemos questão, no Brasil, de dizer que nós somos o oposto disso. Nós valorizamos a existência de muitas raças entre nós. Cada uma com suas características, todas com a capacidade de desenvolver uma vida em comum e de não fazer das suas diferenças motivo para privilégio. E isso é muito importante. (CARDOSO, 1996, p. 5)

Neste viés, o autor percebe "a necessidade de teorizar as 'raças' como elas são, ou seja, constructos sociais, formas de identidade baseadas em uma ideia biológica errônea, mas socialmente eficaz para construir, manter e reproduzir diferenças e privilégios" (GUIMARÃES, 1999). De todo modo, a ideia era de desnaturalização da raça enquanto conceito biológico e fomentar seu caráter sociológico, como instrumento identitário a ser politizado em nome de uma sociedade mais justa e igualitária.

Além disso, o político se apropriou de uma sequência lógico-argumentativa pautada em fatos sociais que tornavam a refutação descabida.

Dessa maneira, o estadista se comprometeu com a perspectiva política esperada em sua imagética naquele período. Neste eixo, na mediação entre grupos dicotômicos, articulou a partir do discurso de união das três raças a possibilidade de sua governabilidade, haja vista as facções antagônicas à sua liderança presidencial. A seguir as propostas que lançou sobre o futuro:

Não queremos que essa perspectiva prevaleça. Acho que a complexidade da nossa formação cultural deve ser usada de uma maneira criativa. Aqui temos discriminação, aqui temos preconceito, mas as aves que aqui gorjeiam, não gorjeiam como lá. Ou seja, não é o mesmo tipo de discriminação, não é o mesmo tipo de preconceito de outras formações culturais. Por isso, nas soluções para esses problemas não devemos simplesmente imitar. Temos que usar a criatividade. A nossa ambiguidade, as características não cartesianas do Brasil, que dificultam em tantos aspectos também podem ajudar em outros. Devemos buscar soluções que não sejam pura e simplesmente a repetição, a cópia de 
Dessarte, ao finalizar o estudioso afirmou que a sociedade brasileira almeja é "o prevalecimento de um espírito de luta afirmativa, cujas diferenças não sejam principal norteador de políticas entre nós'. O termo "ação afirmativa”, “discriminação positiva” desaparece em sua preleção e nasce o termo "luta afirmativa".

No jogo de palavras a mudança de termos desencadeados pelo Presidente, sob análise política, instigou a idealização da solução imaginativa para os dissabores do legado da escravidão à população negra. Agora com ascensão da ala petista ao poder a questão racial assume outro tônus na agenda pública.

\section{O partido dos trabalhadores no poder (2003-2010) e as demandas da militância negra}

Em perspectiva comparada, em 20 de novembro de 2009, Luís Inácio Lula Silva, líder petista, enfatizou o dia Consciência Negra e diz que a Seppir nasceu para responder aos anseios da mulher negra:

Foi por isso que nós criamos a Secretaria Especial de Políticas de Promoção da Igualdade Racial, a SEPPIR, para que ela seja, dentro do governo, o grito dessa mulher negra e a voz altiva da metade negra da nossa população. É como diz a ministra Matilde Ribeiro: a metade negra do nosso povo é a metade pobre do Brasil, é a metade discriminada, é a metade esquecida, é a metade que, há quatro séculos, o Estado brasileiro finge que não vê. (BRASIL, 2003)

A despeito das críticas à Fundação Palmares, o ex-Presidente delineou uma outra projeção para a recém Secretaria criada com ares ministeriais, ou seja, era a figura da mulher negra que associada ao nascimento de políticas públicas que daria conta das mobilizações dos movimentos negros. Talvez o estadista buscasse, à época, evocar a 
construção de gênero para ratificar a sensibilidade, habilidade emocional e conciliação

características depositadas nas mulheres, principalmente ao repetir a fala das feministas negras, como por exemplo Lélia Gonzalez e Sueli Carneiro. ${ }^{17}$

Luís Inácio prosseguiu com marcadores identitários específicos ao grupo feminino

e, desse modo, fugiu das perspectivas condizentes a estrutura machista e patriarcal das

instituições brasileiras. De todo modo, esta seria uma fórmula de caracterizar os fins da

instituição para os movimentos negros, bem como o grau de importância no quadro das

instâncias federais. ${ }^{18}$

${ }^{17}$ Lélia Gonzalez nasceu no dia 1 de fevereiro de 1935 e faleceu no Rio de Janeiro no 10 de julho de 1994. Foi uma intelectual, política, professora e antropóloga brasileira. Lélia Gonzalez foi fundadora (juntamente com outras/outros companheiras/os) do Movimento Negro Unificado (MNU) do Instituto de Pesquisas das Culturas Negras do Rio de Janeiro (IPCN-RJ) do Nzinga Coletivo de Mulheres Negras do Olodum (Salvador). Participou da primeira composição do Conselho Nacional dos Direitos da Mulher (CNDM), de 1985 a 1989. A preocupação com os excluídos das condições de vida digna - nos planos social, político, econômico, educacional, habitacional, de trabalho, de lazer - norteou suas campanhas para cargos públicos, em 1982 (PT) e 1986 (PDT). Graduada em História e em Filosofia, aprofundou estudos nas áreas da Antropologia, da Sociologia, da Literatura, da Psicanálise, da teoria da Estética, da Cultura Brasileira, além de ter-se dedicado profundamente à Ciência, Cultura e História africanas. Em comparação, Sueli Carneiro, nascida em São Paulo (1950) é Doutora em filosofia pela Universidade de São Paulo, foi a fundadora do Instituto Mulher Negra, primeira organização negra e feminista independente de São Paulo, o Géledes. Teórica da questão da mulher criou o único programa brasileiro de orientação na área da saúde física e mental específico para mulheres negras. Em 1988, integrou o Conselho Nacional da Condição Feminina em Brasília, já em 1992 criou o Projeto Rappers de proteção à juventude negra e cidadania. Dentre os prêmios recebidos pelo seu ativismo relacionado à população negra está: Prêmio Benedito Galvão, Prêmio Direitos Humanos pela República Francesa, Prêmio Bertha Lutz e Prêmio de Direitos Humanos Franz de Castro Holzwarth. Em suma, a partir das militantes e intelectuais supracitadas houve o "enegrecimento" da agenda dos movimentos feministas e a "sexualização" dos movimentos negros.

${ }^{18}$ Convém analisar que anteriormente em 2001, a Conferência Mundial contra o Racismo, Discriminação Racial, Xenofobia e Intolerância Correlatas realizou-se na cidade de Durban, África do Sul, ocorreu entre os dias 31 de Agosto e 7 de Setembro de 2001. A Conferência aprofundou a participação dos Estados e uma forte presença brasileira, o evento trouxe algumas mudanças para a política interna do país. Assim, o destaque da participação brasileira vai desde à representatividade como também a participação ativa de ministérios, secretarias, militantes, ONGs e sociedade civil brasileira. Um indicador preciso da importância da presença brasileira em Durban foi a escolha de Edna Roland, da ONG Fala Preta! Como a relatora do evento. Foi de grande destaque a presença massiva de ONGs negras, principalmente ONGs negras feministas, que também buscavam inserir a pauta do feminismo negro no debate, explanando a realidade de exclusão vivenciada pela mulher negra brasileira. Segundo Alves, é notório que houve uma expansão de discussão e ações dentro da temática racial no Brasil, considerando a criação da Secretaria Especial de Políticas de Promoção da Igualdade Racial que parte do reconhecimento do Estado por demandas específicas para a população negra" (ALVES, 2015). Por último, após a Conferência o Brasil como signatário criou uma série de políticas específicas contra a desigualdade racial, cujas mesmas foram: a criação da Seppir, a adoção das ações afirmativas, a Lei n. ${ }^{\circ} 10639$, a criação do Estatuto da Igualdade Racial, a introdução da educação étnico-racial. e a Unilab (RIBEIRO, 2014). 
Em outros termos, se as minorias representativas demandavam direitos e práticas sociais voltadas às mesmas, sob seu governo as respostas estavam sendo sinalizadas que tomariam corpo. Neste ponto, cabe enfatizar a proposição via Poder Executivo de uma instituição com ares feministas. Ou seja, a Seppir seria responsiva não só às categorias raciais, mas também às identidades de gênero e sexuais.

Ademais, Lula atestou que o país não avançava na agenda dos movimentos negros porque a República era branca e os direitos republicanos só alcançavam os brancos: “Os direitos republicanos são monopólio de uma parte da população, como se, na prática, o Brasil fosse uma República branca, ainda que $46 \%$ de seu povo seja negro" (BRASIL, 2003).

Ao fim e ao cabo, esta divergência erigida sob o formato de instituições e das ações afirmativas detectava obstáculos na estrutura social e política que teimavam em prevalecer, na sua fala:

Por isso, meus companheiros e companheiras, eu sei que ainda falta muito, mas nós já vencemos tabus e mais tabus. Nós fizemos quando criamos a Secretaria e, muitas vezes, não fazemos mais porque também não existe o hábito de fazer. (BRASIL,1996)

À luz dos discursos de Lula, podemos entrever na democracia representativa as chances que os grupos minoritários têm para acessar os principais canais estratégicos, bem como introduz a discussão quanto à acomodação de diferentes atores sociais e sua integração no espaço das decisões políticas. Campo este marcado por disputas, para o qual Neves acrescenta no cerne do exame discursivo de Lula:

Pelo diálogo, os agentes abrem-se aos desafios da auto transgressão, ao mesmo tempo em que honram os limites homogeneizadores, conscientizando-se de que as perspectivas são diferenciadas e que não podem ser reduzidas a uma fórmula unitária. O ponto central não é dissolver as diferenças em uma identidade universal, mas sustentar um campo de diferenças múltiplas, não-polarizadas, fluidas e voláteis, e defender a integridade de formas de vida e tradições com as quais os membros de grupos minoritários possam se identificar. Assim, "o princípio da igualdade só se realiza enquanto viabiliza respeito recíproco e simétrico às diferenças". (NEVES, 2001) 
No que tange a criação da Seppir em 2003, a polêmica recai sobre sua gênese enquanto Secretaria Ministerial devido ao orçamento desproporcional entre uma Secretaria com ares ministeriais e um Ministério. Juntamente, a amplitude do diálogo com outros ministérios necessários à construção e aplicação das políticas públicas voltadas à população negra.

É importante perceber que Lula sustenta que a transformação da Secretaria em ares ministeriais ocorreu porque o Deputado Edson não poderia ser chamado de Secretário. A seu ver, seguindo a interpretação de Lula o termo "Secretário" estaria aquém do cargo político, por isso no cargo de Ministro-chefe foi empossado por Lula na Seppir em 2008.

Em linhas gerais, de modo irreverente, o ex-Presidente foge as principais considerações sobre a Seppir e a eficiência da instituição. Nas palavras do ex-Presidente:

No nosso governo, nenhum projeto é bem se não se amplia e melhora as condições de vida dos brasileiros e brasileiras, que historicamente sempre foram deixados para trás, dos que não tinham voz, dos que nunca tinham tido oportunidades. Esse entendimento da ligação indissociável entre desenvolvimento e dignidade humana explica porque decidimos criar, logo no início do nosso primeiro mandato, em 21 de março de 2003, uma Secretaria Especial de Políticas de Promoção da Igualdade Racial, a Seppir, que, logo em seguida, por conta do companheiro Edson, ela teve que ser transformada em Ministério, porque deputado não podia ser Secretário. (BRASIL, 2010)

Ademais, Lula percebe o caráter elitista, preconceituoso e intolerante do país e disse que para dentro do Estado estava sendo alinhada a bandeira dos negros, pobres, mulheres e indígenas, dessa maneira, o tema da raça é mobilizado sob uma etiqueta mais ampla dos excluídos. O que contradiz os objetivos declarados pela instituição: "a Secretaria de Políticas de Promoção da Igualdade Racial da Presidência da República nasce do reconhecimento das lutas históricas dos movimentos negros brasileiro." 
Segundo informe governamental, a Secretaria Especial de Políticas de Promoção da Igualdade Racial (Seppir) foi criada em 21 de março de 2003 a partir da iniciativa do Poder Executivo, sob o governo de Luís Inácio Lula da Silva. ${ }^{19}$

Convém destacar que a Seppir utiliza como referência política o Estatuto da Igualdade Racial (Lei 12.288/2010), que orientou a elaboração do Plano Plurianual (PPA) (2012-2015), resultando na criação de um programa específico intitulado "Enfrentamento ao Racismo e Promoção da Igualdade Racial". Porém, a instituição surge antes do Estatuto da Igualdade Racial suscitado pelos movimentos negros.

No que diz respeito à gestão da Seppir, no âmago da presidência os ocupantes do cargo foram os seguintes nomes: Matilde Ribeiro (2003-2008), Martvz Antonio Alves das Chagas (interino) (2008), Edson Santos (2008-2010) e Eloi Ferreira Araújo (2010). Em comum, todos integraram o Partido dos Trabalhadores (PT) e atuaram na Secretaria Nacional de Combate ao Racismo do (PT).

Coincidentemente, as suas biografias relatam afinidade com a causa racial, em conformidade com a prerrogativa instituída na lei de criação da Seppir, qual seja, que estes fossem militantes da temática racial, com relevância no cenário público. Entretanto, ao longo do governo Lula foram nomeados apenas representantes do Partido dos Trabalhadores, os ativistas da agenda racial oriundos de Ongs, entidades civis e movimentos sociais negros não encontraram espaço no rol da presidência da Seppir.

O que denota certo "favoritismo" de Luís Inácio Lula da Silva pelos integrantes do PT e tendência ao controle político da sua liderança, bem como tendência à "pacificação" das divergências que poderiam ser suscitadas dentro dos quadros institucionais.

\footnotetext{
19، Dentre as funções da Seppir esteve a formulação, coordenação e articulação de políticas e diretrizes para a promoção da igualdade racial; das políticas públicas afirmativas de promoção da igualdade e da proteção dos direitos de indivíduos e grupos étnicos, com ênfase na população negra, afetados por discriminação racial e demais formas de intolerância; articulação, promoção e acompanhamento da execução dos programas de cooperação com organismos nacionais e internacionais, públicos e privados, voltados à implementação da promoção da igualdade racial; coordenação e acompanhamento das políticas transversais de governo para a promoção da igualdade racial; planejamento, coordenação da execução e avaliação do Programa Nacional de Ações Afirmativas; acompanhamento da implementação de legislação de ação afirmativa e definição de ações públicas que visem o cumprimento de acordos, convenções e outros instrumentos congêneres assinados pelo Brasil, nos aspectos relativos à promoção da igualdade e combate à discriminação racial ou étnica”. BRASIL. Secretaria de Políticas de promoção da igualdade racial, 2010. Disponível em:http://www.seppir.gov.br/portalantigo/.arquivos/ DIARIO\%20OFICIAL\%20CNPIR.pdf Acesso em:02/02/2016.
} 
Gomes (2009) acrescenta que Matilde Ribeiro avaliou sua participação na presidência da Seppir como uma continuidade do processo de institucionalização dos movimentos negros, ou seja, a estrutura governamental teria revisto sua postura e prática com relação aos movimentos sociais, bem como a militância negra adequou a pressão política e seu papel de mediação, sobretudo ao pressionar os órgãos públicos para ampliação de políticas. Ademais, segundo Gomes, Matilde disse que os coletivos negros teriam adequado seu linguajar, neste caso deixado o imperativo e assumindo uma agenda negociada com o Estado. Doutro modo, Gomes identificou que a líder da Seppir acomodou o discurso da colaboração e percebeu o desafio para os dois lados.

Em concomitância, na percepção de Gomes, Matilde declarou que o diálogo não é racional, construtivo, e mesmo as críticas costumam não funcionar, ou seja, seria neste novo tom entre Estado e movimentos negros que se fariam as negociações. Ao fim e ao cabo, Matilde informou que importava os princípios que regem esta construção, sobretudo a garantia da autonomia dos movimentos negros em relação ao Estado. Em suma, Gomes versa que após a decisão de criação da Seppir, Matilde e Martvs reuniram diversas entidades dos movimentos negros para discussão da estrutura da Seppir como: a União dos Negros pela Igualdade (UNEGRO), MNU e a Coordenação Nacional das Entidades Negras (CONEN). Este fato expõe o desejo da liderança da Seppir em acomodar os movimentos negros nas instâncias governamentais e fomentar a cooperação, ou mesmo, o diálogo entre atores dicotômicos.

Em comparação, parafraseando Gomes, Martvz Antonio Alves identificou uma interação positiva entre movimentos negros e o Estado. Em outras palavras, haveria o diálogo contínuo entre agentes díspares, bem como o Estado se reportaria aos movimentos negros antes de qualquer execução, porém não da maneira adequada. Para Martvz Antonio, sob as admoestações de Gomes, o movimento exigiria além daquilo que a esfera estatal poderia conceder. Na voz do ex- Presidente da Seppir:

(...) O que eu acho, é legal que o movimento negro saiba que eu acho, é que nós acabamos ajudando o movimento negro a se afirmar. A existência da SEPPIR é a afirmação do movimento negro. "No entanto, a SEPPIR só foi criada pelo fato de que o Movimento Negro reivindicava um espaço de articulação no governo federal, que pudesse dar conta não de todas as políticas que a sociedade brasileira - não posso chamar de 
sociedade... - mas certamente as comunidades afro-brasileiras queriam que o governo federal desenvolvesse. Então, a SEPPIR na verdade foi uma resposta aos anseios do movimento social negro, que eu avalio como vitorioso, é um movimento vitorioso, que sem grandes organizações do ponto de vista da organização tradicional que a gente conhece, sem financiamento, como são os sindicatos, conseguiu durante esses anos, grandes vitórias, né?"20. (GOMES, 2009).

Em patamar diametralmente oposto, segundo os ditames de Gomes, Edson Santos avaliou que dentro dos movimentos negros haveria certo menosprezo pela institucionalidade, bem como para ele a Seppir teria nascido da ação estatal solitária e Lula teria percebido esta necessidade de conciliação e diálogo com os coletivos negros e, assim, tornado o caminho possível. Para tanto, seguindo as considerações de Gomes, Edson reforçou que Lula teria se arregimentado da democracia para fazer o debate adequado e por isto teria concedido o cargo a ele. Portanto, na voz de Edson Santos:

(...) Quer dizer, não há uma ligação, não há uma... infelizmente ainda não há um estreitamento, né, na relação movimento social, ação institucional e governo. É evidente que eu não estou dizendo que eles devem ser cooptados para defender tudo que o governo coloca. Mas que até pode ser contra o governo, em determinadas questões, polemizar com o governo sobre determinados temas. Há uma fragilidade muito grande. $\mathrm{E}$ figuras, hoje, respeitáveis, do Movimento Negro, do movimento social, expressam essa visão, vamos dizer assim, não institucional da luta pela promoção da igualdade racial”. (GOMES, 2009)

Para finalizar, condizente com a participação e cooptação dos movimentos negros pela via estatal, Gomes apresentou a seguinte fala de Sueli Carneiro:

O Geledés, por exemplo, é uma organização que se situa como autônoma e independente de partidos políticos, embora nós nos situemos politicamente à esquerda, mas nós entendemos que a função de organização da sociedade civil é ter uma relação crítica e eventualmente cooperativa em relação ao governo, na medida em que responda às demandas concretas do movimento social. Mas não é uma posição majoritária, digamos, dentro do governo, ao contrário. Eu acho que existe um compromisso muito grande da maior parte das organizações do Movimento Negro com o partido e com o governo, o que eu acho que limita a crítica e não é um fenômeno exclusivo do Movimento Negro; é algo que se percebe em vários outros movimentos sociais". (GOMES, 2009)

\footnotetext{
${ }^{20}$ (grifo nosso).
} 
A Seppir previa a coordenação e articula a formulação e o acompanhamento de políticas públicas com objetivo de incluir a perspectiva racial no conjunto das ações do governo, destacando-se ações de enfrentamento ao racismo e ações afirmativas, tais como: "incorporação da igualdade racial nas políticas governamentais; inclusão da população negra no mercado de trabalho; instituição de medidas de prevenção e enfrentamento do racismo institucional" (BRASIL, SEPPIR, 2003).

Entre as principais competências da Seppir estiveram: "a proposição de diretrizes para a implementação do Programa Nacional de Ação Afirmativa; o estímulo aos órgãos públicos e a sociedade civil para a promoção dos direitos humanos e da eliminação das desigualdades de raça; assegurar a execução de acordos, convenções e programas de intercâmbio e cooperação com organismos nacionais e internacionais". (BRASIL, CNPIR, 2010).

Porém, ao analisarmos a prestação de contas da Secretaria ao Tribunal de Contas da União (TCU) em 2009, descortinamos que a instituição praticou a improbidade administrativa, de acordo com a Lei n. 8.429/1992, a partir do emprego irregular de verbas públicas, bem como má gestão dos administradores públicos.

Em síntese, a auditoria denunciou que a Seppir não cumpria suas metas físicas e financeiras, principalmente no cerne da execução dos programas sociais voltados à questão racial. Por último, asseverou haver falhas nos convênios entre a unidade e as empresas privadas e públicas, identificadas pelo Sistema Integrado de Administração Financeira do Governo Federal (SIAFI) e o Sistema de Convênios (SICONV). No topo das polêmicas estiveram dois objetivos da Seppir: o Pagamento de Indenização aos Ocupantes de Terras demarcadas e Tituladas aos Remanescentes e Reconhecimento, bem como a Demarcação e a Titulação das Áreas de Remanescentes de Quilombos. A primeira atuava com o orçamento, em 2009, de 1.046.004,00 e gastou apenas 0,55.

No comparativo, a segundo detinha 76.000,00 e gastou apenas 5.000,00. A discrepância entre o previsto e o realizado gira em torno de o e 7\%, respectivamente, de acordo com os dados da auditoria supracitada. Ou seja, além dos recursos destinados à Fundação Palmares e ao Incra, a Seppir dispunha de legitimidade orçamentária para 
aplicação do pagamento de indenização das terras demarcadas e tituladas aos remanescentes reconhecidos.

Neste caso, a Seppir não gastou nada e instaurou a hipótese de nenhuma atenção ao tema da distribuição de terras aos remanescentes de quilombos. E ainda que o orçamento fosse baixo para a segunda proposta, em torno de 76.000,00, o gasto de $5.000,00$ elucida que as terras demarcadas e tituladas foram poucas, bem como 0 discurso quanto ao capital humano hábil para tal tarefa ficou sem sentido. Haja vista que a Fundação Palmares detém o cadastramento, a certificação e o reconhecimento dos requisitantes.

Para finalizar, o apoio a iniciativas para Promoção da Igualdade Racial, o saldo orçamentário destinado foi de $344.000,00$ e foi gasto apenas $108.000,00$ cerca de $31 \%$ do orçamento, ou seja, menos da metade estimado em 172.000,00. ${ }^{21}$

Outro ponto de destaque era o Conselho Nacional de Políticas de Igualdade Racial (CNPIR) um órgão colegiado, vinculado à Seppir, de teor consultivo, seu objetivo era propor políticas de promoção da igualdade racial, com ênfase na população negra e outros segmentos raciais e étnicos da população brasileira.

Este órgão era composto da militância negra e nas suas atas são expostas as principais arguições voltadas às políticas afirmativas propostas pela Seppir. Para participar do CNPIR os militantes deveriam ter mais de três anos de história e ações efetivas no mínimo cinco estados e três regiões do Brasil, bem como estas deveriam estar dentro do perfil requisitado pelo edital do Conselho, sobretudo de posse da documentação comprobatória dos critérios sugeridos, em seguida era feita a análise e validação das candidaturas inscritas.

Posteriormente, elas seriam avaliadas por uma comissão específica da CNPIR de seleção e quanto às regras de admissão as mesmas estariam à mercê da cúpula do conselho. A partir dos editais públicos, a entidade deveria atuar na defesa ou garantia dos direitos da população negra e demais segmentos étnico-raciais, os quais sejam:

\footnotetext{
${ }^{21}$ Auditoria da Secretaria de Controle Interno Coordenação-Geral de Auditoria. (2009).
} 
quilombola, cigano, indígena, judeu, árabe, palestino, trabalho, juventudes, gênero, religiosidade, jurídico, cultura, comunicação, educação, saúde e rural.

Fato polêmico no edital de seleção é que seguindo os critérios do campo 3.2 (d) este assinala que a entidade que desenvolver atividades de promoção da igualdade racial em maior número de segmentos constantes do item 2.1, letra " $c$ " do Edital - sendo este os eventos voltados para os ciganos. Contudo, pautada no exame dos movimentos negros citados neste trabalho são poucas as ações ou declarações destes com relação aos ciganos. Além disso, a visualização das lideranças dos movimentos negros no conselho permite a compreensão da diversidade de entidades civis e políticas que irão aderir ou contrastar as medidas efetivadas pelo Governo. ${ }^{22}$

\section{Conclusão}

Em linhas gerais, a pesquisa analisou o equilíbrio de antagonismos entre os atores sociais dicotômicos, bem como indicou a cooptação do simbolismo concernente aos movimentos negros pelos discursos presidenciais, sobretudo a adoção de parte da agenda da militância negra. Ou seja, os avanços obtidos pelos movimentos negros passariam pelo filtro da cidadania regulada. Aos poucos a democracia moderada se abriria

\footnotetext{
${ }^{22}$ Cabendo citar aqui alguns nomes: Rede Amazônica Negra (RAN), Conferência Nacional dos Bispos do Brasil (CNBB), Instituto Gangazumba, Agentes de Pastoral Negros do Brasil (APN'S), Educação e Cidadania de Afrodescendentes e Carentes - Educafro, Movimento Negro Unificado (MNU), Centro de Cultura Negra do Maranhão (CCN/MA), Congresso Nacional AfroBrasileiro (CNAB), Uniao Negros pela Igualdade (UNEGRO), Comunidades Tradicionais de Matriz Africana: Centro de Africaneidade e Resistência Afro-brasileiro (CENARAB), Associação Beneficiente e Recreativa Galpão da Cultura Negra (GALCUNE), Casa de Cultura Ilê Asé Dósoguiã (IAO), Coletivo Nacional de Juventude Negra (ENEGRECER), Fórum Nacional de Juventude Negra (FONAJUNE), Rede Nacional de Negras e Negros Lésbicas, Gays, Bissexuais, Travestis e Transexuais, Articulação de Organização de Mulheres Negras Brasileiras, Fórum Nacional de Mulheres Negras (FMN), Grupo de Mulheres Negras Dandara no Cerrado (GMNDC), Coordenação Nacional de Articulação das Comunidades Negras Rurais- Quilombolas (CONAQ),Central Única dos Trabalhadores (CUT), Federação Nacional das Associações de Pessoas com Doenças Falciformes (FENAFAL), Instituto Nangetu e União Nacional dos Estudantes (UNE). Os relatórios referentes ao conselho presente no Portal da extinta SEPPIR apresentam as dissonâncias e consonâncias entre os movimentos sociais negros. BRASIL. Secretaria de Politicas de promoção da igualdade racial. Seleção das entidades da sociedade civil para integrar o conselho nacional de políticas de promoção da igualdade racial - CNPIR. Edital de convocação. 2010. Disponível em:http://www.seppir.gov.br/portalantigo/.arquivos/DIARIO\%20OFICIAL\%20CNPIR.pdf Acesso em:02/02/2016.
} 

discussões públicas no campo ideológico e da práxis das relações raciais, visto que o berço das animosidades se mantém estruturado. O saber envolto na retórica presidencial procurou assegurar o poder sobre as instituições de recorte racial. Neste caso, saber e poder se mesclam com vistas ao controle político da agenda dos movimentos negros e a contrastiva identidade negra. Doutro modo, as narrativas presidenciais, sobretudo José Sarney, legitimam o saber oficial ante as contestações e o contra-poder suscitado pelos “protestos negros". Os quais podem ser conferidos na proposta de redefinição dos heróis nacionais e combate ao racismo. Ou seja, o poder configurado na arqueologia do mito da democracia racial começa a ruir em Fernando Henrique Cardoso, porém em troca o estadista enaltece o ethos do povo brasileiro com vistas a permanência da imagem harmônica do caldeamento. Neste eixo, Fernando Henrique confirma os interesses políticos e econômicos quanto à sustentação da desigualdade racial e refuta as possíveis soluções consideradas exógenas ao cenário nacional. A exemplo quanto à introdução das ações afirmativas.

Entretanto, a análise em pauta comprovou que o ex-Presidente Lula, em termos de retórica oficial, soube adequar a falência paulatina do mito da democracia racial, em simultaneidade a criação da Seppir e o nascimento do Estatuto da Igualdade Racial. Vale rememorar que o fomento à concepção da Secretaria com ares ministeriais partiu do ativismo negro, logo após a Conferência de Durban (2001). Fato é que neste momento a carta magna da militância negra começa a ser concebida, ainda que possam ser tecidas críticas quanto a este processo. Paralelamente, o racismo à brasileira é desnudado no âmbito do discurso oficial.

Em suma, a agenda de direitos pautada pelos movimentos negros colide não só com interesses contrários da aristocracia política e econômica, mas também encontra entraves nos seus representantes legais representados no Legislativo, Judiciário e, em maior ou menor medida, na figura do Executivo. Todavia, o resultado do histórico das mobilizações negras tem sido condecorada com a garantia constitucional dos direitos 
humanos, a materialização de políticas públicas e a criação das instituições de enfoque racial, apesar das limitações quanto à gestão de recursos e, recentemente, as mudanças nos quadros do executivo.

\section{Referências}

ARRUTI, José Maurício Andion. A emergência dos "remanescentes": notas para o diálogo entre indígenas e quilombolas. MANA, Rio de Janeiro, vol. 3, n. 2, p. 7-38. 1997.

ABREU, Rodrigo Bueno. A marcha contra a farsa da abolição na transição democrática (1988). Revista Contemporânea - [Dossiê 1964-2014: 50 Anos depois, a cultura autoritária em questão] Ano 4, v., n. 5, , 2005. ISSN: 2236-4846. Disponível em:

<http://www.historia.uff.br/nec/sites/default/files/11_A_marcha_contra_a_farsa_da_aboli cao_na_transicao_democratica_1988.pdf $\geq$. Acesso em: 01-02-2017.

ALMEIDA, Alfredo Wagner Berno de. Quilombos: sematologia face a novas identidades. In: Frechal - terra de preto, quilombo reconhecido como reserva extrativista. São Luís: SMDDH/CCN-PVN, 1996.

\section{ALVES, Joyce Amâncio de Aquino. O combate internacional ao racismo a partir da} Conferência de Durban e as implicações na política brasileira. Trabajo preparado para su presentación en el VIII Congreso Latino-americano de Ciencia Política, organizado por la Asociación Latino-americana de Ciência Política (ALACIP). Pontificia Universidad Católica del Perú, Lima, 22 al 24 de julio de 2015.

ANDREWS, George Reid. Blacks and whites: São Paulo, Brazil, 1888-1988. Madison: University of Wisconsin Press, 1991. 376 p

BRASIL. Biblioteca da Presidência da República. José Sarney. Abertura das comemorações do centenário da abolição da escravatura. Brasilia, DF: Palácio do Planalto, 21 de março de 1988. p. 122 Disponível em:

<http://www.biblioteca.presidencia.gov.br/presidencia/ex-Presidentes/josesarney/discursos/1988/23.pdf $\geq$. Acesso em: 01/02/2016. 
BRASIL. Presidência da República Secretaria de Comunicação Social. Biblioteca da Presidência. Construindo a Democracia racial brasileira. Brasília, DF, 1998. Disponível em: http://www.biblioteca.presidencia.gov.br/ex-Presidentes/fernando-henriquecardoso/publicacoes-1/construindo-a-democracia-racial Acesso em:10/01-2010

BRASIL. Presidência da República. Casa Civil. Auditoria. Secretaria de Controle Interno Coordenação-Geral de Auditoria. 2009 Disponível em:http://www.seppir.gov.br/portalantigo/.arquivos/Relatorio\%20de\%20Auditoria\%20de\%2 oGestao.pdf. Acesso em: 01/01/2016

BRASIL. Presidência da República. Decreto $n .^{\circ} 4.887$ de 20 de novembro de 2003. Brasília, DF, 2003. Disponível em:

<http://www.planalto.gov.br/ccivil_03/decreto/2003/d4887.htm>.Acesso em: 01/01/2016

BRASIL. Secretaria de Politicas de Promoção da Igualdade racial. CNPIR: edital de convocação. 2010. Disponível

em:http://www.seppir.gov.br/portalantigo/.arquivos/DIARIO\%20OFICIAL\%20CNPIR.pdf Acesso em:02/02/2016

CAMPOS, Deivison Moacir Cesar. O Grupo Palmares (1971-1978): Um Movimento Negro de Subversão e Resistência pela Construção de um Novo Espaço Social e Simbólico.

Dissertação de Mestrado em História. Pontifícia Universidade Católica do Rio Grande do Sul, Porto Alegre, agosto de 2006.

CARDOSO, Fernando Henrique. Discurso. 1996. Discurso proferido no Seminário Internacional -"Multiculturalismo e Racismo: o Papel Da Ação Afirmativa Nos Estados Democráticos Contemporâneos". Palácio do planalto, Brasília. DF, 2 de julho de 1996. Disponível em:www.biblioteca.presidencia.gov.br/.../02071996\%20\%20Discurso\%20FHC\%20no\%2. Acesso em:02/02/2015

CARNEIRO, Sueli. A batalha de Durban. Estudos Feministas, n. 209-1, 2002. Disponível em: <https://periodicos.ufsc.br/index.php/ref/article/viewFile/9563/8779 >. Acesso em: 01-012018.

CARVALHO, Ana Paula Comin. Tecnologias de governo, regularização de territórios quilombolas, conflitos e respostas estatais. Horizontes Antropológicos, Porto Alegre, ano 22, n. 46, p. 131-157, jul./dez., 2016. Disponível em:

<http://www.scielo.br/pdf/ha/v22n46/0104-7183-ha-22-46-0131.pdf >. Acesso em: 01/02/2016

CONVENÇÃO NACIONAL DO NEGRO, 1986. Disponível em:

<http://www.institutobuzios.org.br/documentos/CONVEN\%C3\%87\%C3\%83O\%20NACIONAL\% 20DO\%20NEGRO\%20PELA\%20CONSTITUTINTE\%201986.pdf>. Acesso em: 01/01/2016, p. 6. 
DOMINGUES, Petrônio. Movimento Negro Brasileiro. Alguns Apontamentos Históricos. 26 de abril de 2006, vol. 12, n. 23, 2006.

FIABANI, Aldemir. Os novos quilombos: luta pela terra e afirmação étnica no Brasil (19882008). 2008. 275f. Tese (Doutorado em História) - Universidade do Vale do Rio dos Sinos, Centro de Ciências Humanas, São Leopoldo, 2008, p. 12

GOMES, Arilson dos Santos. O Trabalhismo e o Movimento Social Negro brasileiro (19431958). Temporalidades - Revista Discente do Programa de Pós-graduação em História da UFMG, vol. 4, n.2, Ago./Dez. 2012.

GOMES, Marcos Vinicius Peinado. O Movimento negro e a Secretaria Especial de Políticas de Promoção da Igualdade Racial: um estudo sobre a luta por sentidos sobre a desigualdade racial no Brasil. 2009. Dissertação de mestrado apresentada à Escola de Administração de Empresas de São Paulo da Fundação Getulio Vargas como requisito para obtenção do título de Mestre em Administração Pública e Governo. São Paulo, 2009

GUARNIEIRI \& SILVA. Cotas Universitárias no Brasil: Análise de uma década de produção científica. Psicologia Escolar e Educacional, SP. v.21, n.2, p. 183-193, maio/ago.de $2017 .$.

GUIMARÃES, Antonio Sérgio Alfredo. Depois da democracia racial. Tempo Social: Revista de Sociologia da USP, São Paulo, v. 18, n. 2, p. 269-287, 1999. Disponível em: http://www.scielo.br/pdf/ts/v18n2/a14v18n2.pdf Acesso em: 01/02/2016, p.64

HANCHARD, Michael George. Orfeu e o poder: o movimento Negro no Rio de Janeiro e São Paulo (1945-1988), trad. Vera Ribeiro. Rio de Janeiro: EdUERJ, 2001, p. 174-175.

HANCHARD, Michael. Orpheus and Power. The Movimento Negro of Rio de Janeiro and São Paulo, Brazil, 1945-1988. Princeton, Princeton University Press, 1994, 203 p.

LEITE, Ilka Boaventura. Quilombos e quilombolas: cidadania ou folclorização? Horizontes Antropológicos, Porto Alegre, n. 10, p. 123-149, maio 1999. Disponível em: <http://www.scielo.br/pdf/ha/v5n10/0104-7183-ha-5-10-0123.pdf>. Acesso em: 02/02/2014

MATTOS, Alexandre José Barreto de. Questão quilombola e defesa nacional: a Ilha da Marambaia como estudo de caso. / Contra-Almirante (FN). Rio de Janeiro: ESG, 2012. Disponível em: <http://www.esg.br/images/Monografias/2012/MATTOS.pdf >. Acesso em: 02/02/2017.

MUNANGA, Kabenguele. Rediscutindo a mestiçagem no Brasil: identidade negra. Petrópolis, RJ:Vozes, 1999. 
NEVES, Marcelo. Justiça e diferença numa sociedade global complexa. In: SOUZA, Jesse (Org.) Democracia hoje: novos desafios para a teoria democrática. Brasília, DF: UnB, 2001. p. 334

PEREIRA, Amilcar Araujo. O Mundo Negro: a constituição do movimento negro contemporâneo no Brasil (1970-1995). 2010. 268 f. Tese (Doutorado em História) Universidade Federal Fluminense, Instituto de Ciências Humanas e Filosofia, -. Niterói, 2010. Disponível em: <http://www.historia.uff.br/stricto/td/1254.pdf>. Acesso em: $02 / 02 / 2016$

RIBEIRO, Matilde. Mulheres negras: uma trajetória de criatividade, determinação e organização. Estudos Feministas. Florianópolis, v.16, n.3, p. 424, set./dez.,2008. Disponível em: http://www.scielo.br/pdf/ref/v16n3/17.pdf Acesso em: 01-02-2010

RIBEIRO, Matilde. Políticas de Promoção da Igualdade Racial. Impulso às ações afirmativas e à educação étnicorracial. Revista Pedagógica, vol.15, n.33., p.109-126, Jul/dez 2014.

SANTANA, Carlos. Abdias Nascimento: Atuação de um negro no parlamento brasileiro 1983-1986. Revista Digital Simonsen. 2015, p. 102-106.

SANTOS, Joel Rufino dos. "Movimento negro e crise brasileira", Atrás do muro da noite; dinâmica das culturas afro-brasileiras, Joel Rufino dos Santos e Wilson do Nascimento Barbosa, Brasília, Ministério da Cultura/Fundação Cultural Palmares, 1994, p. 157.

SANTOS, Márcio André de Oliveira. A persistência dos movimentos negros brasileiros: processo de mobilização à $3^{\text {a }}$ Conferência Mundial das nações Unidas contra o racismo. 2005. Dissertação (Mestrado em Ciência Política). UERJ, IFCH, , Rio de Janeiro, 2005.

SILVA, Joselina da. A União dos Homens de Cor: aspectos do movimento negro dos anos 1940 e 1950. Revista Estudos Afro-asiáticos, Ano 25, n. ${ }^{\circ}$ 2, 2003, p. 215-235.

SILVA, Luiz Inácio Lula da. Discurso, 2009. Discurso durante cerimônia de comemoração do Dia Nacional da Consciência Negra, Salvador-BA, 20 de novembro de 2009. Disponível em: http://www.biblioteca.presidencia.gov.br/presidencia/ex-Presidentes/luiz-inacio-lulada-silva/discursos/20-mandato/2009/20-11-2009-discurso-do-Presidente-da-republica-luizinacio-lula-da-silva-durante-cerimonia-de-comemoracao-do-dia-nacional-da-consciencianegra. Acesso em: 01/01/2016. 
SILVA, Luiz Inácio Lula da. Discurso. 2010. Discurso durante cerimônia de sanção do Estatuto da Igualdade Racial e do projeto de lei que cria a Universidade Federal da Integração Luso-Afro-Brasileira (Unilab). 2010. Disponível em:http://www.biblioteca.presidencia.gov.br/presidencia/ex-Presidentes/luiz-inacio-lulada silva/discursos/20-mandato/2010/20-07-2010-discurso-do-Presidente-da-republica-luizinacio-lula-da-silva-durante-cerimonia-de-sancao-do-estatuto-da-igualdade-racial. Acesso em: 01/01/2016.

WERNECK, J. A luta continua: O combate ao racismo no Brasil pós-Durban. Revista do Observatório da Cidadania, n. 55, 2005. Disponível em:http://www.socialwatch.org/sites/ default/files/pdf/en/panorbrasileirod2005_bra.pdf. Acesso em: 01 jun. 2007.

Recebido em 15/01/2017 Aprovado em 30/05/2018

Universidade do Estado de Santa Catarina - UDESC

Programa de Pós-Graduação em História - PPGH

Revista Tempo e Argumento Volume 10 - Número 25 - Ano 2018 tempoeargumento@gmail.com 